\title{
The Feasibility of Writing Learning Videos for Elementary School Students
}

\section{* Kadek Tatanika Wiratsari1*, I Gede Margunayasa²,}

1,2,3 Program Studi Pendidikan Guru Sekolah Dasar. Universitas Pendidikan Ganesha, Indonesia

\section{A R T I C L E I N F O}

Article history:

Received in revised form

12 January 2021

Accepted 28 January 2021

Available online 25

February 2021

Kata Kunci:

Video Pembelajaran,

Menulis

Keywords:

Learning Video, Writing

\begin{abstract}
A B S T R A K
Siswa kelas rendah masih kesulitan dalam menulis, keterlambatan menulis dapat menghambat proses pembelajaran. Penelitian ini bertujuan untuk menciptakan pengembangan produk video pembelajaran menulis untuk siswa kelas I SD dan mengembangkan video pembelajaran menulis untuk siswa kelas I SD dan mengembangkan video pembelajaran menulis untuk siswa kelas I SD yang teruji validitasnya. Penelitian ini mengacu pada prosedur model pengembangan ADDIE. Namun, karena keterbatasan waktu, tenaga, sumber daya, dan finansial maka penelitian ini tidak melaksanakan tahap implementation dan evaluation. Subjek penelitian ini adalah 2 ahli materi, 2 ahli media, dan 2 praktisi. Objek penelitian ini adalah validitas video pembelajaran menulis. Pengumpulan data penelitian ini menggunakan metode kuesioner dengan memberikan lembar penilaian kepada dua orang dosen ahli media, dua dosen ahli materi, dan dua orang guru kelas I SD. Data hasil validasi dari para ahli kemudian
\end{abstract} dianalisis menggunakan rumus mean untuk mengetahui rata-rata skor validitas video pembelajaran menulis. Hasil analisis menunjukan bahwa rata-rata skor validasi video pembelajaran menulis yakni 4.44 dengan kualifikasi sangat baik dan rata-rata skor validasi materi video pembelajaran menulis yakni 4.06 dengan kualifikasi sangat baik. Berdasarkan hasil analisis tersebut, video pembelajaran menulis untuk siswa kelas I SD dinyatakan valid dan memiliki kualifikasi sangat baik.

\section{A B S T R A C T}

Low-grade students still have difficulty in writing. Writing delays can hinder the learning process. This study aimed to develop writing learning video products for first-grade elementary school students whose validity has been tested. This research refers to the ADDIE development model procedure. However, this study did not implement and evaluate stages due to limited time, effort, resources, and finance. The subjects of this study were two material experts, two media experts, and two practitioners. The object of this research is the validity of the writing learning video. The data collection of this research used a questionnaire method by providing assessment sheets to two media expert lecturers, two material expert lecturers, and two first-grade elementary school teachers. The data from the validation results from the experts were then analyzed using the mean formula to determine the average validity score of the writing learning videos. The analysis results showed that the average validation score for writing learning videos is 4.44 with very good criteria. The average score of validation for writing learning video materials is 4.06 with very good criteria. Based on the analysis results, the writing learning video for first-grade students of SD was declared valid and had very good criteria.

\section{Introduction}

Elementary school students still need help in understanding the learning material provided by the teacher, both learning assistance, skills, attitudes, character guidance, health which are carried out directly or indirectly (Vidergor, 2021; Wang et al., 2021; Zhou et al., 2021). Elementary school students, especially low-grade students, still do not have the independence to understand the material given (Handayani et al., 2020). Students who need the help of supporting media to understand the material are 
first-grade students. First-grade students are starting to know how to write, read, and count. Learning materials will not be effective for students (S. M. Dewi et al., 2021; Kurniawan et al., 2020; Mutiarawati, 2020). Learning to write, read, and count is basic for first-grade elementary school students. When learning online, first-grade elementary school students still depend on the help of parents (Anugrahana, 2020). So it can be said that first-grade elementary school students still need help, guidance, explanation, assistance, and direction when students learn.

However, parents cannot teach their children, which discourages them from learning because they do not understand the explanations given by the parents (Handayani et al., 2020). Parents who work from home (WFH) must continue to accompany their children, especially their children, in the first grade of elementary school. Technology has not been evenly introduced in learning media, such as laptops, gadgets, and others (Jamaludin, 2020). Online learning also experiences problems in terms of using online learning media. Teachers who are not accustomed to using online learning media must try even harder to adapt their abilities to the demands of online learning (Rusdiana \& Nugroho, 2017). The task given by the teacher in the process has a very short time in each different subject which makes students confused in completing the assignment (Barseli et al., 2020). Even though not all students understand the material presented, understanding the material provided is not comprehensive. Students only understand it based on interpretations or perspectives from students (Asmuni, 2020). Students are also not free to ask the teacher about material that is not clear in online learning. The provision of the material provided by the teacher is sometimes less varied so that it affects student understanding (Handayani et al., 2020). In addition, low-grade students, especially first-grade students, still have difficulty writing. Writing delays can hinder the learning process and difficulty in obtaining knowledge and information (Nasution, 2017). Students have difficulty writing because they have not memorized the alphabet and are still having difficulty distinguishing letter shapes. Another obstacle in writing delay in writing is the media that is not yet available (B. R. Dewi, 2020). It can affect the student learning process because students will have difficulty and experience delays in receiving the learning given. So we need learning media that can support the learning process of first-grade students learning to write. Learning media is very necessary because teachers have difficulty teaching students in writing during distance learning. The use of instructional media makes it easier for students to teach and make the learning process more effective, but it can make the learning process more attractive (Amir et al., 2016).

One solution that can help students in the learning process is learning media that presents visual, audio, and multimedia, attracting students' interest in learning and presenting an interesting display. (Riyadi \& Mulyono, 2016). Media that can support first-grade elementary school students to learn, especially writing, is instructional videos. Instructional videos that focus on writing are still difficult to find in the first grade of elementary school. It was supported based on the results of distributing questionnaires on November 6-11, 2020. First-grade teachers that $83.3 \%$ stated that writing learning videos for first-grade students were difficult to find. In addition, $16.7 \%$ of first-grade teachers stated that writing learning videos were made by themselves to provide learning to students. Then the first-grade teacher stated that $75 \%$ stated that they strongly agreed to develop writing learning videos, and $25 \%$ stated that they agreed that writing learning videos were developed in first-grade elementary school students. Video learning is one of the learning media that can activate the sense of hearing and sight (Turyati, Moh. Muchtarom, 2016). Learning videos allow students to learn without being in class and without the position of the teacher directly (Borko et al., 2008). Learning using video can provide effective learning results (Smyrni \& Nikopoulos, 2010). When receiving learning via video, students can focus on the learning material provided, support responsive learning situations, and help play the role of a teacher (Richards et al., 2021). Learning videos can help students to understand the delivery of material that is more meaningful or less verbal, adds a new dimension in learning that presents moving images, which are seen in real terms, and can overcome the limitations of time and space (Parlindungan et al., 2020; Radiusman \& Simanjuntak, 2020; Yuanta, 2019). Learning videos can help students try learning videos themselves at any time, and students can condition the learning process. Learning videos are also able to optimize active learning for students (Ilsa et al., 2020). The use of instructional videos can streamline children's sensory abilities and explain content more realistically. Video lessons implemented regardless of space and time can improve learning achievement and increase students' cognitive abilities (Nursafitri et al., 2021).

A learning video that is focused on one of the materials will attract students' attention. Instructional videos can be used to analyze behavior patterns and online video-based learning (Yoon et al., 2021). The influence of subtitles learning video media helps additional demands on learning to assess understanding and learning outcomes (Tarchi et al., 2021). Instructional videos in anomaly can be used in public places (Nayak et al., 2021). Learning videos with the FLIP approach of students consistently increase every week to watch the video given each step logically completed leading to the next step, 
instructional videos, instruction handouts, worksheet assignments, spreadsheet completion, and model answers (Walsh et al., 2021). Learning videos for students with the subject matter of 6 grade four elementary schools are feasible with very good categories showing that the learning videos show the percentage of $90.62 \%$ practical use (Prananda, 2020). Use vocab board media in pre-writing learning that learning media for pre-writing is effective for elementary school students (Luthfiana et al., 2020). It gets effectiveness of 0.5 , including the moderate criteria. Management skills influence performance video on cognitive activity and cognitive load (Kramer et al., 2020). Video game-based learning programs to help develop skills (Díaz et al., 2021). Instructional videos that help medical students to perform surgical procedures (Nazari et al., 2020). Free online study videos for medical genetics material (Maggipinto et al., 2020). Producing distance learning and active videos for students (Lipomi, 2020). So, instructional video media have a positive influence in helping the learning process effectively.

However, there were no instructional videos that focused on learning for first-grade elementary school students about writing. Writing learning videos need to be developed because writing learning videos are still difficult to find. No one has yet developed writing learning videos for first-grade elementary school students. So that writing learning videos were developed that could help first-grade students of elementary school to learn to write. With writing learning videos, students will learn through instructional videos followed by students to write because writing videos can provide color, sound, movement, and a process (Wisada et al., 2019). The video that is given contains sound, movement, interesting pictures, and of course, it attracts students' concentration to learn to write. Video learning to write is also easier to understand to explain a process, handle space and time, and be watched again, stopped as needed, and more realistic. This study aimed to develop writing learning video products for first-grade elementary school students whose validity has been tested. The purpose of developing writing learning videos is to create writing learning video products for first-grade elementary school students and develop tested writing learning videos for first-grade elementary school students. It is hoped that instructional videos can help students learn to write and help teachers in the learning process.

\section{Method}

Research on developing writing learning videos for first-grade elementary school used the ADDIE model (analysis, design, development, implementation, and evaluation) as a reference. Several stages were carried out in developing the writing learning video; analysis, design, and development for implementation and evaluation were not carried out due to limited resources, energy, time, and finance. The analysis stage consists of analyzing student characteristics, needs analysis, media analysis, and curriculum analysis. The design stage was carried out by designing a writing learning video for first-grade elementary school students from determining the overall media concept until the learning video was completed. The development stage was carried out by developing a design that has been made and receiving advice from supervisors. After the development was carried out, it was continued with a media expert test, a material expert test by a competent lecturer in their field. Two practitioners gave an assessment sheet for writing learning videos to determine the validity of the instructional videos that had been developed. Then the review results were analyzed, then a product revision was made of the writing learning video based on reviews from experts and practitioners.

The research subjects for developing writing learning videos are two material experts, two media experts, and two practical people. At the same time, the object of research is the validity of the writing learning video media. The data used in this development research are qualitative and quantitative. The method used in data collection is the questionnaire distribution. The questionnaire is a data collection technique that gives respondents a set of questions or written statements to answer online or offline (Sugiyono, 2018). This study used an instrument in the form of a rating scale. The rating scale is data in the form of numbers that can be interpreted descriptively, such as bad-good, positive-negative, and bigsmall. Ratings in the form of a rating scale are based on a certain scale. The rating scale of this study uses a scale of 5-1 (Ilhami \& Rimantho, 2017). The validation instrument for writing learning videos showed in Tables 1, 2, and 3 .

Table 1. Instrument validation of instructional videos by media experts

\begin{tabular}{cllc}
\hline No. & \multicolumn{1}{c}{ Aspect } & \multicolumn{1}{c}{ Indicator } & Number \\
\hline 1 & Visual & a. Image clarity & 1 \\
& & b. Shooting suitability & 2 \\
& & c. colors, backgrounds, images, and animations & 3 \\
& d. The speed at which the image moves & 4 \\
\hline
\end{tabular}




\begin{tabular}{cllc}
\hline No. & \multicolumn{1}{c}{ Aspect } & \multicolumn{1}{c}{ Indicator } & Number \\
\hline \multirow{2}{*}{2} & \multirow{2}{*}{ Audio } & e. Lighting accuracy & 5 \\
& & a. Voice clarity & 6 \\
& & b. Rhythm & 7 \\
3 & \multirow{2}{*}{ Typography } & c. Music suitability & 8 \\
& & a. Selection of text type & 9 \\
\multirow{2}{*}{4} & Presentation & b. Text size accuracy & 10 \\
& & a. Interesting & 11 \\
& & b. Duration & 12 \\
\hline Total & & c. The clarity of the storyline & 13 \\
\hline
\end{tabular}

Table 2. Instrument validation of instructional videos by material experts

\begin{tabular}{|c|c|c|c|}
\hline No. & Aspect & Indicator & Number \\
\hline \multirow[t]{4}{*}{1} & Material & a. Clarity of learning material & 1 \\
\hline & & b. The suitability of the learning video with the learning objectives & 2 \\
\hline & & c. The suitability of the learning video with the learning material & 3 \\
\hline & & d. The accuracy of the distribution and order of the material & 4 \\
\hline \multirow[t]{4}{*}{2} & Language & a. Suitability of the language with the rules of the Indonesian language & 5 \\
\hline & & b. The sentences used are easy to understand and understand & 6 \\
\hline & & c. The communicative nature of the language used & 7 \\
\hline & & d. Language level with student cognitive & 8 \\
\hline Tota & & & 8 \\
\hline
\end{tabular}

Table 3. Instrument validation of learning videos by practitioners

\begin{tabular}{|c|c|c|c|}
\hline No & Aspect & Indicator & Number \\
\hline \multirow[t]{5}{*}{1} & Visual & a. Image clarity & 1 \\
\hline & & b. Shooting suitability & 2 \\
\hline & & c. colors, backgrounds, images, and animations & 3 \\
\hline & & $\mathrm{d}$. The speed at which the image moves & 4 \\
\hline & & e. Lighting accuracy & 5 \\
\hline \multirow[t]{3}{*}{2} & Audio & a. Voice clarity & 6 \\
\hline & & b. Rhythm of sound & 7 \\
\hline & & c. Music suitability & 8 \\
\hline \multirow[t]{2}{*}{3} & Typography & a. Selection of text type & 9 \\
\hline & & b. Text size accuracy & 10 \\
\hline \multirow[t]{4}{*}{4} & Material & a. Clarity of learning material & 11 \\
\hline & & b. The suitability of the learning video with the learning objectives & 12 \\
\hline & & c. The suitability of the learning video with the learning material & 13 \\
\hline & & $\mathrm{d}$. The accuracy of the distribution and order of the material & 14 \\
\hline \multirow[t]{4}{*}{5} & Language & a. Suitability of the language with the rules of the Indonesian language & 15 \\
\hline & & b. The sentences used are easy to understand and understand & 16 \\
\hline & & c. The communicative nature of the language used & 17 \\
\hline & & d. Language level with student cognitive & 18 \\
\hline \multirow[t]{3}{*}{6} & Cohesiveness & a. Interesting & 19 \\
\hline & & b. Duration & 20 \\
\hline & & c. The clarity of the storyline & 21 \\
\hline \multicolumn{2}{|c|}{ Total } & & 21 \\
\hline
\end{tabular}

The instrument grid created was carried out by arranging the instruments and then continuing the expert's assessment. The instrument is said to be good if it meets the content validity requirements. After that, the calculation of the content validity of the Gregory formula was carried out. It was obtained that the content validity value of the instruments compiled obtained the content validity coefficient in the range 0.80-1.00 with very high content validity criteria. For methods and techniques using descriptive 
qualitative and quantitative data analysis. The qualitative descriptive method processes data from input, responses, criticism, and suggestions from experts and practitioners related to the developed media. Meanwhile, the quantitative descriptive method is used to obtain the score of each expert through the expert assessment sheet. The score obtained is calculated as an average to determine the validity of the media developed by applying the mean formula. The average score obtained was converted using the 5 scale conversion guideline to obtain the media validity results.

\section{Result and Discussion}

\section{Analysis Stage}

The analysis stage was carried out through several stages: needs analysis, student characteristics analysis, curriculum analysis, and media analysis. Analysis of needs based on questionnaires showed that $83.3 \%$ of teachers stated that writing learning videos were not made by themselves. Writing learning videos for first-grade elementary school students was difficult to find. Analysis of the characteristics of first-grade elementary school students is in the concrete operational stage (7-11 years), which when receiving learning requires concrete objects that students can find. The analysis of the writing learning curriculum for first-grade elementary school students is on theme 2 about "my hobby". There are several criteria for media analysis in developing instructional videos, visual, audio, typography, language, material, and presentation aspects. Visual aspects consisted of media identity, color, writing, letters, and media layout and attractiveness. The criteria for the audio aspect consisted of sound clarity. Typography aspect criteria consisted of the suitability of the type of text. Criteria for language aspects consist of language use, language standardization, sentence effectiveness, and word use. The material aspect was the media's ability to explain the material, the material's completeness, and the material's attractiveness to the media. The criteria for the aspect of presentation are also related to media use and media attractiveness.

\section{Design Stage}

The design stage was carried out after the analysis stage. The design begins with determining the overall instructional video design, including visual, audio, typography, language, material, and presentation aspects. The instructional video design was obtained, making instructional video designs, making storylines for videos, designing video opening covers, making learning video techniques, tools, and materials used to record videos. The video was made by recording himself explaining material with a tripod, green-screen, microphone, whiteboard, markers, and gadgets. The material presentation starts from lesson opening of the lesson, the core of the material, and the closing. To produce an attractive video requires an application that helps form a kinemaster application with a 16: 9 ratio. In the learning video, images, audio, and a selection of interesting backgrounds for students are added. The instructional video design can be presented in Table 4 .

Table 4. Design of a writing learning video for first-grade students of elementary school

\begin{tabular}{|c|c|c|c|c|}
\hline No & Scenario & Animation & Duration & Location \\
\hline 1 & $\begin{array}{l}\text { Type shoot: } \\
-\quad \text { Personal identity } \\
-\quad \text { Video title } \\
-\quad \text { Researcher's name } \\
-\quad \text { The name of the supervisor } \\
-\quad \text { Ganesha University of EducationLatar } \\
\quad \text { Video } \\
\text { - White background } \\
\text { Music Background } \\
-\quad \text { Talk To Me }\end{array}$ & $\begin{array}{l}\text { Opening Learning Videos } \\
\text { Animations: } \\
\text { - Flip the Cube } \\
\text { - Colorful Shapes }\end{array}$ & $\begin{array}{l}00.00- \\
13.29 \\
\text { minute }\end{array}$ & Home \\
\hline 2 & $\begin{array}{l}\text { Type shoot: } \\
-\quad \text { Greet students } \\
-\quad \text { Introduce myself } \\
-\quad \text { Delivering the purpose of learning to } \\
\text { write } \\
-\quad \text { Conducting apperception to students } \\
\text { Video Background } \\
-\quad \text { Classroom setting }\end{array}$ & $\begin{array}{l}\text { Writing learning opener } \\
\text { Animations: } \\
-\quad \text { Swipe right entry } \\
\text { animation } \\
-\quad \text { Left sliding exit } \\
\text { animation }\end{array}$ & $\begin{array}{l}01.05- \\
02.14 \\
\text { minute }\end{array}$ & Home \\
\hline
\end{tabular}




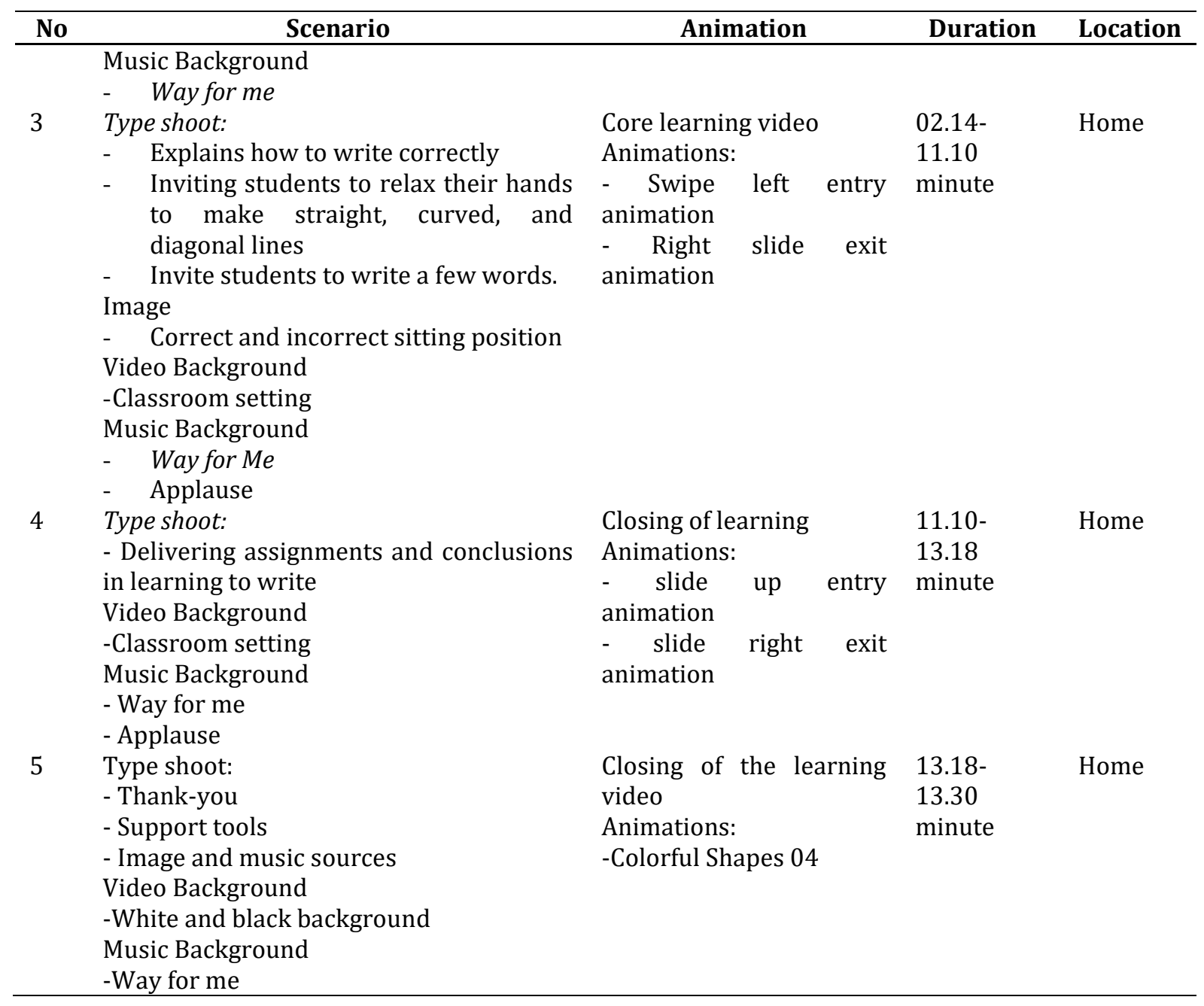

\section{Development Stage}

The learning video developed consists of a video opener, a learning opener, a core in material delivery, a learning cover, a video closing on the learning video. The video opener is designed with a color composition that appeals to students, attractive images, and matches first-grade students' attractiveness. At the video's opening, the author's name and identity and the supervisor's name are displayed at 00.0100.07 minutes. Learning openers are designed by opening learning to greet students, introduce themselves, and give perceptions to students in the minutes 00.08-02.13. The core of learning is designed by delivering learning material which is found at 02.13-04.12 minutes. The learning core conveys the correct preparation for starting writing (how to sit, hold a pencil, put a book, the distance between the book and the book, and choose a bright place). Then the delivery of material makes straight lines, diagonal lines, and curved lines available at 04.12-06.20 minutes. Then the students were invited to learn to write by writing a few words: Bali, Edo, Cina, paku, and Siti. Submission of material to write a few words is available at $06.20-11.10$ minutes. Furthermore, students are given the task to train students' ability to write after watching writing learning videos. The closing of the learning video is available at 11.10-13.18 minutes. The video cover is designed by displaying the thank you sentence and displaying the supporting tools for video creation, image sources, and music sources. The closing of the learning video is available at 13.18-13.30 minutes. The development stage is presented in Table 5.

After the learning video has been developed, it followed a validation test for the experts to determine the validity of the media being developed. The validity test was carried out online and offline by providing assessment sheets to two media experts, two material experts, and two practitioners. Based on the results of trials that have been carried out by providing assessment sheets to experts, the average validation score and criteria of writing learning videos for first-grade students of elementary school are obtained in Table 6 and Table 7. 
Table 5. The development stage of writing learning videos for first-grade students of elementary school

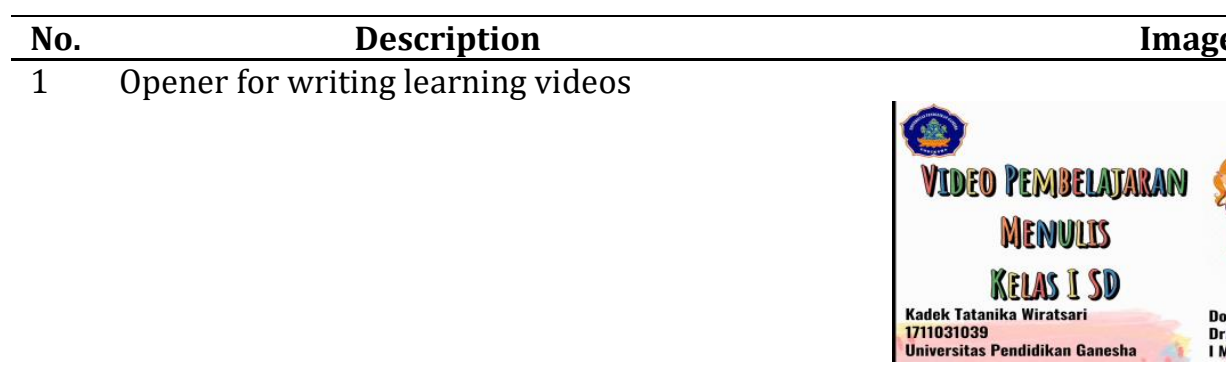

2 Opener learning to write

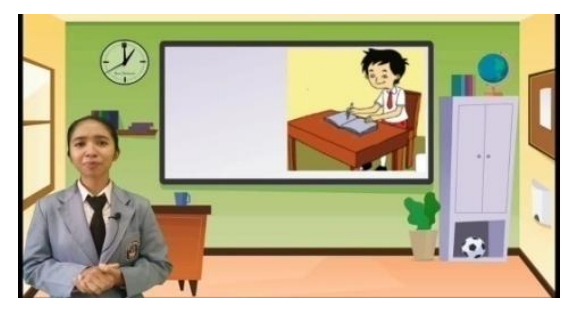

3 Preparation of learning to write

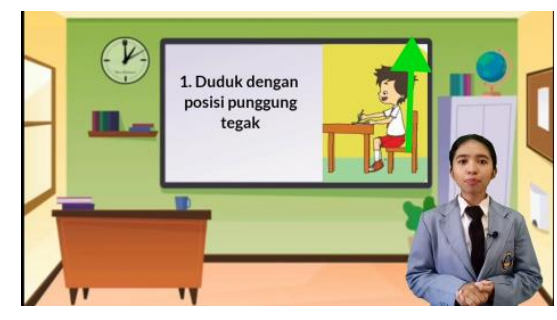

4 Make straight, diagonal, and curved lines

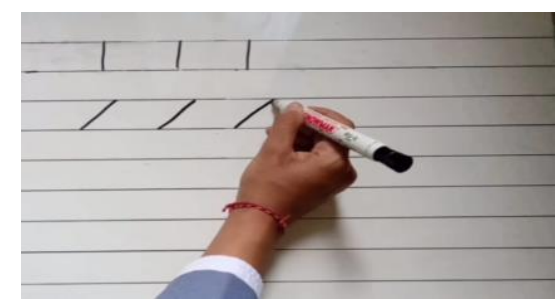

$5 \quad$ Make a few words

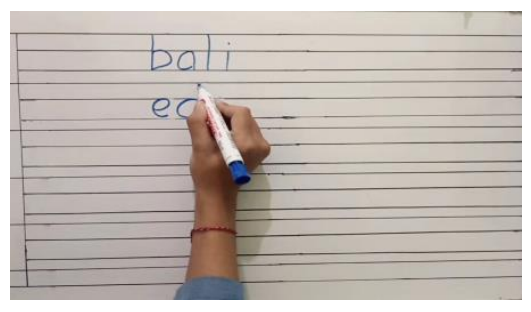

6 Closing of the learning video

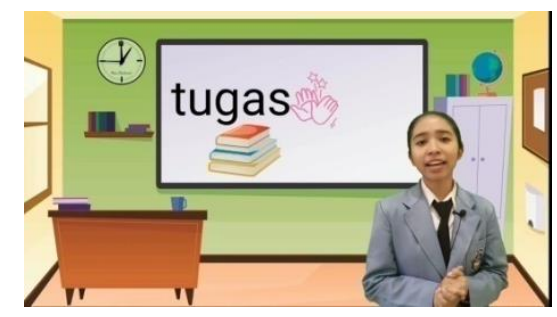




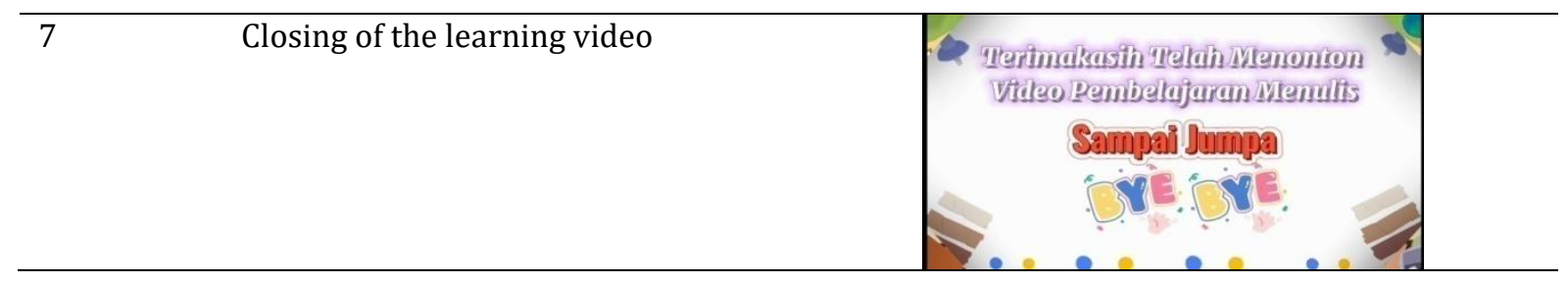

Table 6. The average score of validation of writing learning videos for first-grade students of elementary school

\begin{tabular}{|c|c|c|c|}
\hline No & Assessment items & Average & Category \\
\hline 1 & The material image can be seen clearly & 5 & Very good \\
\hline 2 & $\begin{array}{l}\text { Taking the picture size is suitable for first-grade students of } \\
\text { elementary school }\end{array}$ & 4 & Very good \\
\hline 3 & $\begin{array}{l}\text { Selection of colors, backgrounds, text, images, and interesting } \\
\text { animations }\end{array}$ & 4.5 & Very good \\
\hline 4 & $\begin{array}{l}\text { The speed of motion of the images is suitable for first graders of } \\
\text { elementary school }\end{array}$ & 4.25 & Very good \\
\hline 5 & Image lighting is correct & 4.75 & Very good \\
\hline 6 & The narrator's voice is clear and informative & 4.75 & Very good \\
\hline 7 & $\begin{array}{l}\text { The sound presented by the narrator is according to the needs of } \\
\text { first-grade students (not too slow and not too fast) }\end{array}$ & 4.5 & Very good \\
\hline 8 & Music sounds according to the atmosphere and image display & 4.25 & Very good \\
\hline 9 & The text type is easy to read & 4.25 & Very good \\
\hline 10 & The text size is appropriate (not too small and not too big) & 4.25 & Very good \\
\hline 11 & The appearance and presentation of the material has an appeal & 4.5 & Very good \\
\hline 12 & The duration setting is suitable for first-grade students & 4 & Very good \\
\hline \multirow[t]{2}{*}{13} & The presentation of the material has a clear storyline & 4.75 & Very good \\
\hline & Total & 4.44 & Very good \\
\hline
\end{tabular}

Table 7. The average score of the validation of writing learning video material for first-grade students of elementary school

\begin{tabular}{clcc}
\hline No & \multicolumn{1}{c}{ Assessment items } & Average & Criteria \\
\hline 1 & The material in the learning video is clear & 4.75 & Very good \\
2 & Learning objectives in the learning video & 4.5 & Very good \\
3 & & 4.5 & Very good \\
4 & The learning material in the learning video is appropriate & 4.75 & Very good \\
5 & $\begin{array}{l}\text { In the learning video, the material distribution and sequencing } \\
\text { are correct }\end{array}$ & 4.5 & Very good \\
& & & \\
& $\begin{array}{l}\text { The language used in the learning video is following the rules of } \\
\text { the Indonesian language }\end{array}$ & 4.25 & Very good \\
7 & $\begin{array}{l}\text { The sentences used in the learning videos are easy to understand } \\
\text { and understand }\end{array}$ & 4.75 & Very good \\
8 & The language used in the learning video is communicative & 5 & Very good \\
\hline & $\quad$ Total & $\mathbf{4 . 0 6}$ & Very good \\
\hline
\end{tabular}

Based on the data in Table 6 and Table 7, it can be seen that each indicator gets an average score of $3.75<\mathrm{X} \leq 5$. The data validation analysis of instructional video media shows that the average learning video gets a score of 4.44. At the same time, the results of the analysis of the instructional video material show that the average learning video gets a score of 4.06. Based on the five scale conversion guidelines listed in Table 6 and Table 7, each assessment item has very good criteria. After getting the validation results from media experts, material experts, and practitioners, comments and suggestions are taken into consideration to improve the learning videos that have been developed. The comments and suggestions given are clear pronunciation, the arrangement of text and images must be neat, and instructions must be consistent, which must be improved. 


\section{Discussion}

The results showed that the writing learning video was valid and suitable for first-grade elementary school students. The development of research on writing learning videos for first-grade elementary school students is different from developing other instructional videos. No one has developed writing learning videos for first-grade elementary school students with material that explains how to write correctly, relaxes the fingers, and even writes words for first-grade students. SD. The explanation of the writing learning video material is explained systematically. It is easy for students to understand because the student learning videos are invited directly to writing from letters, syllables, and words. This video can also be used regardless of space and time for students to learn to write according to the student's condition and the student's grasp of both students who receive learning slowly or quickly. Students can also repeat the writing learning video over and over again until the students can write well. Writing learning videos follow the characteristics of first-grade elementary school students who still need guidance, direction, companion, assistance, and guidance in the learning process. Writing learning videos can invite students to learn to write to seem real like in class. Therefore, writing learning videos is effectively used for first-grade elementary school students who are still at the concrete operational stage. Thus, writing learning videos can increase student motivation and student learning outcomes, both cognitively and affective students. First-grade writing learning videos can also support student motivation to learn to write, train themselves to learn to write because writing learning videos are fun for students so that it arouses students' curiosity and enthusiasm in learning and can increase student understanding (Hung et al., 2018)

Six aspects were considered in the writing learning videos. The visual aspects consisted of media identity, attractive colors, easy-to-read writing, letters, and neat layout and attractiveness of the video learning for students. The criteria for the audio aspect consist of a rhythm that follows the learning situation and the clarity of the voice that students can hear clearly. Typography aspect criteria consist of the suitability of the type of text that is attractive and easy to read. The criteria for language aspects consist of using language that follows the enhanced spelling, the standardization of the language that follows the learning situation, the effectiveness of the sentences in the delivery of the material, and the use of words following rules or polite. The material aspects criteria were related to the instructional video's ability to explain writing material well and easily. According to first-grade elementary school students of elementary school, the material completeness and the attractiveness of the material in the writing learning video. The criteria for the presentation aspect related to instructional videos that can be used anytime and anywhere, and the attractiveness of instructional videos can attract students' interest in learning to write.

Writing learning videos can provide messages that students can receive, can be more easily understood to explain a process. It can be used anywhere to overcome space and time, be watched again and stopped according to needs, and are more realistic, can affect student attitudes and provide a deep impression for students. Writing learning videos help teachers deliver material to overcome space and time and can clarify the message the teacher wants to convey about writing material Writing learning videos can attract students' attention to writing lessons (Ningsih, 2019; Patty, 2015). The use of instructional media in writing learning videos helps first-grade elementary school students understand the correct sitting position, draw lines, form letters, arrange syllables, and become words. When students watch writing learning videos, students will not feel stiff or tense. The writing learning video invites students to learn in a comfortable position and attracts students' attention in learning to write with the visualization of the learning video displayed (Bétrancourt \& Benetos, 2018).

\section{Conclusion}

Based on the research results that have been carried out, it can be concluded that the writing learning video is valid. The results obtained by the writing learning video are supported by six criteria aspects of writing learning videos, visual aspects, audio aspects, typography aspects, material aspects, linguistic aspects, and presentation aspects. These results can help students be motivated to learn to write, help students understand letter shapes, arrange syllables and words and learn to write for elementary students to attract the attention and interest of students in learning.

\section{References}

Amir, A., Matematika, D. P., \& Padangsidimpuan, I. (2016). Penggunaan Media Gambar dalam Pembelajaran Matematika. Jurnal Eksakta, 2(1), 34-40.

Anugrahana, A. (2020). Hambatan, Solusi dan Harapan: Pembelajaran Daring Selama Masa Pandemi 
Covid-19 Oleh Guru Sekolah Dasar. Scholaria: Jurnal Pendidikan Dan Kebudayaan, 10(3), 282-289. https://doi.org/10.24246/j.js.2020.v10.i3.p282-289.

Arsyad, A. (2014). Media Pembelajaran. PT Raya Grafindo Persada.

Asmuni, A. (2020). Problematika Pembelajaran Daring di Masa Pandemi Covid-19 dan Solusi Pemecahannya. Jurnal Paedagogy, 7(4), 281. https://doi.org/10.33394/jp.v7i4.2941.

Barseli, M., Ifdil, I., \& Fitria, L. (2020). Stress akademik akibat Covid-19. Jurnal Penelitian Guru Indonesia, 5(2), 95-99.

Bétrancourt, M., \& Benetos, K. (2018). Why and when does instructional video facilitate learning? A commentary to the special issue "developments and trends in learning with instructional video." Computers in Human Behavior, 89, 471-475. https://doi.org/10.1016/j.chb.2018.08.035.

Borko, H., Jacobs, J., Eiteljorg, E., \& Pittman, M. E. (2008). Video as a tool for fostering productive discussions in mathematics professional development. Teaching and Teacher Education, 24(2), 417-436. https://doi.org/10.1016/j.tate.2006.11.012.

Dewi, B. R. (2020). Analisis Pembelajaran Membaca dan Menulis Pada Siswa Kelas 1 di SDN Jatimulyo 1 Malang.

Dewi, S. M., Prawiyogi, A. G., Anwar, A. S., \& Wahyuni, C. S. (2021). Efektivitas Strategi Direct Reading Thingking Activities terhadap Peningkatan Kemampuan Membaca Pemahaman Di Sekolah Dasar. Jurnal Basicedu, 5(1), 453-455. https://doi.org/10.31004/basicedu.v5i1.786.

Díaz, J., López, J. A., Sepúlveda, S., Ramírez Villegas, G. M., Ahumada, D., \& Moreira, F. (2021). Evaluating Aspects of Usability in Video Game-Based Programming Learning Platforms. Procedia Computer Science, 181, 247-254. https://doi.org/10.1016/j.procs.2021.01.141.

Handayani, T., Khasanah, H. N., \& Yoshinta, R. (2020). Pendampingan Belajar Di Rumah Bagi Siswa Sekolah Dasar Terdampak Covid-19. ABDIPRAJA (Jurnal Pengabdian Kepada Masyarakat), 1(1), 107. https://doi.org/10.31002/abdipraja.v1i1.3209.

Hung, I.-C., Kinshuk, \& Chen, N.-S. (2018). Embodied interactive video lectures for improving learning comprehension and retention. Computers \& Education, 117, 116-131. https://doi.org/10.1016/j.compedu.2017.10.005.

Ilhami, R. S., \& Rimantho, D. (2017). Penilaian Kinerja Karyawan dengan Metode AHP dan Rating Scale. Jurnal Optimasi Sistem Industri, 16(2), 150-157. https://doi.org/https://doi.org/10.25077/josi.v16.n2.p150-157.2017.

Ilsa, A., F, F., \& Harun, M. (2020). Pengembangan Video Pembelajaran dengan Menggunakan Aplikasi Powerdirector 18 di Sekolah Dasar. Jurnal Basicedu, 5(1), 288-300. https://doi.org/10.31004/basicedu.v5i1.643.

Jamaludin. (2020). Pembelajaran Daring Masa Pandemi Covid-19 Pada Calon Guru: Hambatan, Solusi, dan Proyeksi. E-Jurnal. UIN Sunan Gunung Djati Bandung.

Kramer, C., König, J., Strauß, S., \& Kaspar, K. (2020). Classroom videos or transcripts? A quasi-experimental study to assess the effects of media-based learning on pre-service teachers' situation-specific skills of classroom management. International Journal of Educational Research, 103, 101624. https://doi.org/10.1016/j.ijer.2020.101624.

Kurniawan, M. H. D., Mujiwati, E. S., \& Kurnia, I. (2020). Meta-Analisis Pengaruh Strategi Pq4r Dalam Pembelajaran Bahasa Indonesia Di Sekolah Dasar. Prima Magistra: Jurnal Ilmiah Kependidikan, 1(2), 153-159. https://doi.org/10.37478/jpm.v1i2.614.

Lipomi, D. J. (2020). Video for Active and Remote Learning. Trends in Chemistry, 2(6), 483-485. https://doi.org/10.1016/j.trechm.2020.03.003.

Luthfiana, Sari, Y., \& Ulia, N. (2020). Pengembangan Media "Vocab Board" Dalam Meningkatkan Keterampilan Membaca Menulis Permulaaan (MMP) Siswa Kelas I SDN Kedalingan. Orphanet Journal of Rare Diseases, 21(1), 1-9.

Maggipinto, S., Chen, A., Huynh, D., Heutlinger, O., Eberenz, K., Mallick, S., Marshall, T., Desai, R., Wolbrink, T. A., \& Boone, P. M. (2020). Free, online videos for distance learning in medical genetics. $\begin{array}{lllll}\text { European Journal of } & 03983 .\end{array}$ https://doi.org/10.1016/j.ejmg.2020.103983.

Mutiarawati, R. (2020). Persepsi Siswa Tentang Lingkungan Belajar Bahasa. 4(2), 135-143.

Nasution, P. R. (2017). Perbedaan Peningkatan Kemampuan Berpikir Kreatif Matematis Dan Kemandirian Belajar Siswa Pada Pembelajaran Berbasis Masalah Dan Pembelajaran Konvensional Di Smpn 4 Padangsidimpuan Puspa. Peidagogeo, 2(1), 46-62.

Nayak, R., Pati, U. C., \& Das, S. K. (2021). A comprehensive review on deep learning-based methods for video anomaly detection. Image and Vision Computing, 106, 104078. https://doi.org/10.1016/j.imavis.2020.104078.

Nazari, T., van de Graaf, F. W., Dankbaar, M. E. W., Lange, J. F., van Merriënboer, J. J. G., \& Wiggers, T. 
(2020). One Step at a Time: Step by Step Versus Continuous Video-Based Learning to Prepare Medical Students for Performing Surgical Procedures. Journal of Surgical Education, 77(4), 779787. https://doi.org/10.1016/j.jsurg.2020.02.020.

Ningsih, I. H. (2019). Peran Guru Dalam Pembelajaran Menulis Permulaan Menghadi Abad 21. BASINDO : Jurnal Kajian Bahasa, Sastra Indonesia, Dan Pembelajarannya, 3(1), 38-43. https://doi.org/10.17977/um007v3i12019p038.

Nursafitri, L., Purwanti, E., \& Fitriyah, F. (2021). Pelatihan Video Pembelajaran Kreatif di Era New Normal bagi Guru PAUD di Kecamatan Tanjung Bintang, Lampung Selatan. Abdimas: Jurnal Pengabdian Masyarakat Universitas Merdeka Malang, 6(1), 35-42. https://doi.org/10.26905/abdimas.v1i1.4919.

Parlindungan, D. P., Mahardika, G. P., \& Yulinar, D. (2020). Efektivitas Media Pembelajaran Berbasis Video Pembelajaran dalam Pembelajaran Jarak Jauh ( PJJ) di SD Islam An-Nuriyah.

Patty, R. (2015). Pengembangan Model Induktif Kata Bergambar Pada Pembelajaran Menulis Permulaan Di Kelas II SD. Sekolah Dasar, 24(2), 172-179.

Prananda, G. (2020). Pengembngan Media Video Pembelajaran Tema 6 Subtema 2 Untuk Siswa Kelas SD Negeri 17 Pasar Masurai 1. Jurnal Dharma PGSD, 1(1), 38-45.

Radiusman, \& Simanjuntak, M. (2020). Analisis Video Pembelajaran Matematika Mahasiswa PGSD Universitas Mataram Pada Mata Kuliah Pembelajaran Matematika SD. Jurnal Pembelajaran Matematika Inovatif, 3(6), 615-624. https://doi.org/10.22460/jpmi.v3i6.615-624.

Richards, J., Altshuler, M., Sherin, B. L., Sherin, M. G., \& Leatherwood, C. J. (2021). Complexities and opportunities in teachers' generation of videos from their own classrooms. Learning, Culture and Social Interaction, 28(September 2020), 100490. https: //doi.org/10.1016/j.lcsi.2021.100490.

Riyadi, D., \& Mulyono, H. (2016). Pengembangan Media Pembelajaran Berbasis Multimedia Pada Mata Kuliah Bidang Studi dan Kependidikan. PGSD FKIP Universitas Sebelas Maret.

Rusdiana, E., \& Nugroho, A. (2017). Respon pada Pembelajaran Daring bagi Mahasiswa Mata Kuliah $\begin{array}{llll}\text { Pengantar Hukum Integralistik, } & \text { 19(2), }\end{array}$ https://journal.unnes.ac.id/nju/index.php/integralistik/article/view/21834/.

Smyrni, P. N., \& Nikopoulos, C. (2010). Evaluasting the Impact of Video-Based Versus Traditional Lectires on Student Learning. Educational Research, 1(8), 304-311.

Sugiyono, P. D. (2018). Metode Penelitian Kuantitatif, Kualitatif, dan R\&D. Alfabeta.

Tarchi, C., Zaccoletti, S., \& Mason, L. (2021). Learning from text, video, or subtitles: A comparative analysis. Computers \& Education, 160, 104034. https://doi.org/10.1016/j.compedu.2020.104034.

Turyati, Moh. Muchtarom, dan W. (2016). Pengaruh Penggunaan Media Video Edukasi Terhadap Hasil Belajar Pkn Siswa Kelas VII SMP Negeri 2 Gondangrejo. Journal of Chemical Information and Modeling, 53(9), 1689-1699.

Vidergor, H. E. (2021). Effects of digital escape room on gameful experience, collaboration, and motivation of elementary school students. Computers \& Education, 166, 104156. https://doi.org/10.1016/j.compedu.2021.104156.

Walsh, J. N., Brien, M. P. O., \& Costin, Y. (2021). The International Journal of Management Education Investigating student engagement with intentional content: An exploratory study of instructional videos. The International Journal of Management Education, 19(2), 100505. https://doi.org/10.1016/j.ijme.2021.100505.

Wang, Y., Huebner, E. S., \& Tian, L. (2021). Parent-child cohesion, self-esteem, and academic achievement: The longitudinal relations among elementary school students. Learning and Instruction, 73, 101467. https://doi.org/10.1016/j.learninstruc.2021.101467.

Wisada, P. D., Sudarma, I. K., \& Yuda S, A. I. W. I. (2019). Pengembangan Media Video Pembelajaran Berorientasi Pendidikan Karakter. Journal of Education Technology, 3(3), 140. https://doi.org/10.23887/jet.v3i3.21735.

Yoon, M., Lee, J., \& Jo, I.-H. (2021). Video learning analytics: Investigating behavioral patterns and learner clusters in video-based online learning. The Internet and Higher Education, 50, 100806. https://doi.org/10.1016/j.iheduc.2021.100806.

Yuanta, F. (2019). Pengembangan Media Video Pembelajaran Ilmu Pengetahuan Sosial pada Siswa Sekolah Dasar. Trapsila: Jurnal Pendidikan Dasar, 1(2), 91-100.

Zhou, J., Huebner, E. S., \& Tian, L. (2021). Co-developmental trajectories of psychological need satisfactions at school: Relations to mental health and academic functioning in Chinese elementary school $\begin{array}{lllll}\text { students. Learning } & \text { Instruction, } & \text { 74, }\end{array}$ https://doi.org/10.1016/j.learninstruc.2021.101465. 